\title{
Development of spatial thinking in first year students of engineering specialties
}

\author{
Tatyana Belavina ${ }^{10000-0003-3676-5227] ~}$ \\ ${ }^{1}$ Kazan State University of Architecture and Engineering, 420043, Zelenaya st., Kazan, Russia
}

\begin{abstract}
The article considers issues of development of spatial thinking in students in the process of studying graphic disciplines. The relevance of the study is dictated by the specifics of competencies in the application of the laws of geometric formation of the future builder. The subject of the study is the formation of spatial thinking among engineering students through the study of the course of engineering and computer graphics. The peculiarity of the student's spatial thinking is manifested through the perception of reality, the ability to see the design result, the combination of actions and operations, as well as graphic visualization skills. The obtained results revealed the dependence of the conditions of reproduction of the form by students (reproductive knowledge) on their mastery of theoretical knowledge and acquired skills in performing images.
\end{abstract}

Keywords: spatial thinking, engineering graphics, projections of geometric images, spatial imagination, spatial thinking of students.

\section{Introduction}

Recent studies related to the study of spatial thinking [1] show that spatial thinking skills are strongly correlated with advances in science, technology, engineering, and mathematics (STEM), and have a marked impact on learning in educational institutions, thereby improving the quality of education.

The development of spatial thinking begins in childhood, when learning of the world through visual images takes place and introducing them to spatial thinking can contribute to overall mathematical and cognitive development [2]. Thus, the use of planar and spatial geometric images can increase the level of spatial perception and according to research [3] significantly improve the quality of knowledge and skills during learning.

Spatial thinking can be characterised as part of visual thinking. Visual thinking activities are related in particular to modelling, designing, constructing [4]. All these activities are related to the educational tasks of civil engineers. In addition, spatial thinking stimulates the development of an innovative way of thinking that transforms spatial forms into digital forms [5]. The transition to digital technologies in the design of demonstration space leads to the development of the construction industry, industrial and civil engineering, and environmental design. Traditional design drawings are increasingly unable to meet the new contextual communication requirements of contemporary architectural culture in terms of mode of expression [6].

Quality engineering education is impossible without a high level of graphic training of construction university students. Professional competence of an engineer implies conscious 
application of knowledge, skills and abilities required for solving certain engineering tasks; ability to develop design and technological documentation; fluent orientation in the environment of graphic information technologies. The application of computer technologies in education creates the conditions for active and competent use of computer technologies and modern digital technologies in the future [7-10]. The implementation of such innovative approaches to learning will allow students to independently solve the tasks in their future professional activities [11, 12].

The discipline «Engineering and Computer Graphics» belongs to the group of disciplines that form the basis of engineering education and includes the main sections of descriptive geometry and engineering graphics. At our university, in all engineering disciplines, this discipline is taught in the first year. The discipline is studied both in the classical way «by hand», despite the existing opinion that with the development of digital technologies in creating graphic images, descriptive geometry and traditional design have become obsolete [13], and with the help of the graphics program AutoCAD. It should be noted that the efficiency of using computer graphics depends on the knowledge of basic image theory and the ability to use it in graphic modelling in computer environment [14]. Nowadays, computer has become an indispensable tool in visual communication, environmental design, industrial modelling and other fields [15].However, mastering this discipline is complicated by the lack of basic drawing knowledge, as the subject «drawing» has been abandoned in Russian schools since the nineties. Besides, the teaching of school geometry is somewhat different from the teaching of engineering drawing. Poor development of students' spatial thinking [16], which serves as an essential component in preparing future builders for engineering practice, is also one of the reasons for the complexity of teaching this discipline. At the same time, it should also be noted that students, while receiving education in the discipline «Engineering and Computer Graphics», acquire computer modeling skills necessary in future professional activities, both at the design and construction stages [17].

Developing imagination is an important prerequisite for mastering the ability to construct and read drawings and graphic activities in general. As adequate verification of a constructive solution requires spatial reasoning skills to represent imaginative tasks [18-19]. An experimental study conducted at the University of La Laguna with the purpose of mastering spatial thinking in students has shown the importance of spatial abilities in the context of engineering education [20].

\section{Materials and methods}

The study of most special disciplines in construction university is based on the competences acquired by students in the process of studying graphic disciplines, which requires establishing a clear sequence of learning, defining teaching methods that contribute to the successful assimilation of theoretical and practical knowledge. Successful learning of other graphical disciplines in higher education guarantees good knowledge of the fundamentals of descriptive geometry and engineering graphics.

Professional graphic competence of an engineer implies conscious application of graphic knowledge, skills and abilities; experience in graphic professionally oriented activities; free orientation in the environment of graphic information technologies; attitude towards successful professional activity, its significance and certain engineering tasks [21].

The practice of teaching first-year students in the discipline «Engineering and Computer Graphics» reveals poor development of students' spatial thinking. This is evidenced by the 
difficulties encountered by students of higher educational institutions in solving both theoretical and practical problems.

Spatial thinking is a complex process. With the help of spatial thinking a person can orient in space, create three-dimensional images and objects, perform various actions in the process of solving all kinds of engineering problems.

One of the problems in the formation of spatial thinking, spatial imagination in first year students are spatial representations, without which mastering the discipline is impossible. The process of forming spatial representations of geometric objects takes place on the basis of knowledge about them. A condition ensuring the formation of spatial representations is to teach first-year students the techniques and methods of theoretical foundations of building images of geometric objects, their diversity and relations between them.

The basic principle of mastering the engineering and computer graphics course is to teach elementary techniques, which are characterised by reliance on visual material. The most important prerequisite for the formation of ideas about objects is to teach students how to look at and remember details and reproduce them from memory, as well as to master the techniques that students need to create images when reading a drawing based on the perception of the plane image [22].

In addition, the process of mastering knowledge in Engineering and Computer Graphics should include four stages: understanding, memorising, applying knowledge according to the rules and solving creative tasks. The stages are related to the activity of recognising, reproducing, solving typical and non-typical graphic tasks that require application of knowledge in new situations. Therefore, it is desirable to include creative tasks in the learning process, the solution of which is aimed at assimilation of relevant knowledge. And this, naturally, will contribute to the process of knowledge assimilation and development of spatial thinking, without which professional engineering activity is impossible in the future.

It should be noted that models, parts, various products, drawings, etc. should be used during the engineering graphics course. The study of theoretical material should be combined with compulsory graphic work. The main goal of traditional «manual» graphic training is the development of spatial thinking on the basis of projection drawing methods and mastering drawing technology with the help of an ordinary drawing tool.

An important requirement for students' graphic training is the introduction of modern 3D information technologies. Continuous improvement of CAD systems, which are supplemented with new commands, functions and modules, allows solving a large number of engineering tasks: creating $2 \mathrm{D}$ and $3 \mathrm{D}$ graphic objects, performing various engineering calculations, etc.

\section{Results and discussion}

The introduction of teaching methods using 3D technology [23] makes it possible to greatly simplify the process of formation of spatial thinking, spatial imagination in students. For example, in the study of full theoretical course of engineering graphics by Chinese university students [24], it was found that the course content should strengthen the ability of students' spatial imagination and help them to master the method of information expression to improve their practical and applied abilities.

Our experiment [25] has shown that the most effective way is to draw the part in a computer programme and then, having an idea of it, to draw it on a sheet of paper. This way, the student can visualize the model of the part in advance and it will be easier for him to draw it on the sheet of paper. If the student knows the basics of AutoCAD and has enough curiosity, the task will take much less time than the same work with a pencil, here the superiority of machine execution of the task is unambiguous. However, it is impossible 
to work in AutoCAD without knowing the algorithms of its execution, whether it is the intersection of surfaces or the construction of a figure. For example, the article [26] suggests using the computer graphic editors AutoCAD and Compass in solving the problems in the subject «Descriptive geometry and engineering graphics», the authors of the article point out the role of pedagogical information technologies in the process of teaching students at universities in Uzbekistan. At the same time there are other approaches to teaching computer graphics, where practical classes are transferred from the standard graphics API OpenGL to the game development engine Unity. Game Development Engines (GDEs) provide powerful programming tools and computational components. Software development in GDEs is done using full-fledged IDEs [27]. We believe that the use of computer graphics in the learning process contributes to a better mastering of basic concepts, methods, acquisition of practical skills and abilities, development of spatial thinking. And as a consequence, the efficiency of students' independent work increases, the quality of completed homework and tests improves. The authors [28] believe that with the development of computer technology, engineering graphics have more expressive approaches and can effectively express innovative design ideas. The engineering graphics course should develop students' abilities of spatial imagination, digital and programmatic expression for drawing and preliminary innovative design [29].

\section{Conclusions}

During the study of graphical disciplines students should learn to develop and use graphical technical documentation; use in practice new knowledge and skills necessary for the development of design, regulatory, operational and technical documentation for the objects of professional activity; conduct design of parts and assemblies of building structures in accordance with technical tasks using standard packages and means of computer aided design.

As a result of mastering the discipline, students acquire the knowledge they need for further studies at university and their professional activities.

We believe that the success of the discipline «Engineering and Computer Graphics» contributes to the development of spatial imagination and skills of proper logical thinking. It also improves the ability of students - from a flat image to mentally create representations of the shape of an object and vice versa, to create images of mentally created images. At the same time, the process of teaching descriptive geometry and engineering graphics serves as one of the most important means of developing imagination.

The inclusion of Engineering and Computer Graphics as one of the main disciplines allows the formation and development of students' spatial thinking, which, in turn, will prepare professional specialists at university who are ready to carry out projects of various degrees of complexity.

This discipline teaches students to master expressive technical language - the language of drawing, the ability to compose and freely read drawings, to solve various engineering and technical problems with the help of drawings. In addition, the discipline also encourages students to develop spatial perceptions and spatial imagination, qualities that characterise a high level of engineering thinking and are necessary for solving applied problems.

\section{References}


1. K. M Gagnier, K. R. Fisher, Cognitive Research: Principles and Implications5(1),29 (2020) DOI: 10.1186/s41235-020-00222-9

2. Gilar Jatisunda, M. Hidayanti, M. Lita, (...), U. Cahyaningsih, V. Suciawati, Journal of Physics: Conference Series, 1778(1), $012017 \quad$ (2021) DOI:10.1088/1742$6596 / 1778 / 1 / 012017$

3. G. A. Totikova, A. A. Yessaliyev, N. K. Madiyarov, N. Medetbekova, European Journal of Contemporary Education, 9(4), 902-914 (2020) DOI: 10.13187/ejced.2020.4.902

4. M. V. Tarasova, The role of visual thinking development in improving the quality of higher education, in materials of All-Russian scientific-methodical conference with international participation Improving the quality of higher education. P.2, 191-195, Krasnoyarsk, Russia, (2009)

5. C. Si-Hang, W. Yun-Long, E3S Web of Conferences,236,05091 (2021) DOI: 0.1051/e3sconf $/ 202123605091$

6. G. Wan Bao, E3S Web of Conferences,236,05072 (2021) DOI: 10.1051/e3sconf/202123605072

7. N.V. Novik, Society: sociology, psychology, pedagogy(Krasnodar, Horse, 8, 88-90, 2016)

8. N.V. Novik, Russian Scientific Journal. Autonomous non-profit organization Ryazan Institute of Economic, Legal, Political and Sociological Research and Expertise: Ryazan, 5, 43, 170-173 (2014)

9. E. V. Koposov, T. N. Prakhova, D. V. Monich, Standards and quality, 9, 88-90 (2011).

10. M. R. Safiullin, E. M. Akhmetshin, International Journal of Engineering and Advanced Technology, 9, 1,7387-7390 (2019) DOI: 10.35940/ijeat.A3097.109119

11. S. A. Hossain Maghool, S. H. Moeini, Y. Arefazar, IJAR, 12(3), 246-272 (2018) DOI: 10.26687/archnet-ijar.v12i3.1719

12. A. Garcia, J. Abrego, J. Jauregui, Universal Journal of Educational Research,7(1),95105 (2019) DOI: 10.13189/ujer.2019.0 70113

13. A. Riekstins, Journal of Architecture and Urbanism,42(1), $34-39$ (2018) DOI 10.3846/jau.2018.1476

14. D. Y. Kim, Sustainability (Switzerland), 11(16), 4416 (2019) DOI: 10.3390/su11164416

15. B. Pu, L. Bao, K. Yang, Journal of Physics: Conference Series, 1744(3),032040 (2021) DOI: $10.1088 / 1742-6596 / 1744 / 3 / 032040$

16. G. E. Tukeyeva, Issues of Science and Education,5(50),175-189 (2019)

17. A. Galiano-Garrigós, M. D. Andújar-Montoya, International Journal of Sustainable Development and Planning, 13(1), 1-11(2018) DOI: 10.2495/SDP-V13-N1-1-11

18. N.V. Norina, V.A. Norin, Y.V. Pukharenko,A/Z ITU Journal of the Faculty of Architecture, 16(3), 71-86 (2019) DOI: 10.5505/itujfa.2019.91489

19. H. L. Rauf, S. S. Shareef, E. Ukabi, International Journal of Recent Technology and Engineering, 8(3), 3201-3207 (2019) DOI: 10.35940/ijrte.C4919.09831

20. M. Contero, F. Naya, P. Company, J.L. Saorin, J. Conesa, IEEE Computer Graphics and Applications, 25(5), 24-31 (2005) DOI: 10.1109/MCG.2005.107

21.V. M. Arapov, The role of geometric and graphic training in the formation of competencies of graduates of technical universities, in Materials of the VI All-Russian Scientific and Methodological Conference Problems of practical training of students, VGTA, 2008,154-162, Voronezh, Russia (2008)

22. E. V. Larionova, O. M. Bukova, Professional education, 7, 15-19 (2018)

23. T. V. Belavina, V. S. Anisimov, O. V. Koval, Sravnitel'nyy analiz metodov obucheniya inzhenernoy grafike, inAbstracts of the 70th International Scientific Conference on Problems of Architecture and Construction, 10-24 April 2018, Kazan, Russia (2018)

24. X. Li, Advances in Intelligent Systems and Computing, 1296, 924-927 (2021) 
25. T. Belavina, T. Gorskaya, M. Goulkanyan, IOP Conf. Ser.: Mater. Sci. Eng, 012173 (2020) DOI: 10.1088/1757-899X/890/1/012173

26. B. D. Ulugov, F. Nurmatov, S. Durmonova, (...), P. Khaliyarov, J. Saynazov, Annals of the Romanian Society for Cell Biology,25(2), 4038-4056

27. D. M. Hmeljak, H. Zhang, Developing a Computer Graphics Course with a Game Development Engine(Annual Conference on Innovation and Technology in Computer Science Education, ITiCSE) 75-81 (2020) DOI: 10.1145/3341525.3387428

28. W. Bu, Lecture Notes in Mechanical Engineering,181-190 (2020)DOI: 10.1007/978-3030-22041-9_21

29. L. Danchenko, N. Tuktamyshov, IOP Conf. Ser.: Mater. Sci. Eng., 890, 012170 (2020) DOI: $10.1088 / 1757-899 X / 890 / 1 / 012170$ 